\title{
Equilibrium Effects of Firm Subsidies Online Appendix
}

\author{
By Martin RotemberG*
}

\section{Alternate Models for Generating $\beta$ and $\theta$}

\section{A. Lucas Span-of-Control Model}

In this section, I show that the direct and indirect effects derived in Section 3 also follow from a decreasing returns to scale model a la Lucas, Robert E (1978). When possible, I try to keep notation for the relevant parameters the same as in the main text, though for simplicity I omit the disturbance terms and productivity growth, consider only one input (labor), and ignore multiple product firms \& product characteristics. I maintain the assumptions, a single final good $Q_{s}$ is produced by a representative firm in a perfectly competitive market, and that the utility function of the representative consumer is

$$
U=\sum_{s=1}^{S} Q_{s}^{\phi}+c
$$

where $c$ is consumption of the outside good, whose price is normalized to one, and the post-tax income of the consumer is assumed to be $I$. Demand for the final good must satisfy

$$
Q=\left(\frac{P}{\phi}\right)^{\frac{1}{\phi-1}}
$$

* Economics Department, New York University. mrotemberg@nyu.edu. 
where $P$ is the price charged by the final good producer.

The final goods producer treats the output from each intermediate good producer as homogeneous:

$$
Q=\sum_{j=1}^{N} q_{j} .
$$

Each intermediate good producer has a decreasing returns to scale production function in labor,

$$
q_{j}=A_{j} L_{j}^{\alpha},
$$

where $A_{j}$ is firm-specific TFP, and $\alpha \in(0,1)$ is the production function elasticity. There is an output subsidy $\left(\tau_{y}\right)$, adjusting the relative price received by each firm, so firm $j$ 's revenue is

$$
y_{j}=\left(1+\tau_{y_{j}}\right) P L_{j}^{\beta},
$$

and profits are given by

$$
\pi_{j}=\left(1+\tau_{y_{j}}\right) p_{j} y_{j}-p_{L} L_{j}
$$

where $p_{L}$ is the price of labor (the wage). Since the intermediate goods in each sector are homogeneous, in equilibrium they will all charge the same price, which will be the same price charged by the final good producer, $P$. Each intermediate good firm profit-maximizing in each sector chooses labor 
to satisfy

$$
L_{j}=\left(\frac{p_{L}}{\left(1+\tau_{y_{j}}\right) P A_{j} \alpha}\right)^{\frac{1}{\alpha-1}} .
$$

Plugging equations 5 and 2 into equation 1 and taking the growth rates yields

$$
\hat{P}=\frac{\frac{\alpha}{\alpha-1}}{\left(\frac{\alpha}{1-\alpha}+\frac{1}{1-\phi}\right)} \sum_{j=1}^{N}\left[\left(\frac{\widehat{1}}{\left(1+\tau_{y_{j}}\right)}\right) \frac{q_{j}}{\sum_{k=1}^{N} q_{k s}}\right]
$$

Plugging into equation 4 allows us to generate how the revenue of each firm grows as the firm-specific subsidies grow:

$$
\hat{y}_{j}=\frac{2-\alpha}{1-\alpha} \frac{\frac{\alpha}{\alpha-1}}{\left(\frac{\alpha}{1-\alpha}+\frac{1}{1-\phi}\right)} \sum_{l=1}^{N}\left[\left(\frac{1}{\left(1+\tau_{y_{j}}\right)}\right) \frac{q_{l s}}{\sum_{k=1}^{N} Q_{k s}}\right]-\frac{2-\alpha}{1-\alpha}\left(\frac{1}{\left(1+\tau_{y_{j}}\right)}\right)
$$

and

$$
\hat{Y}=\left(1-\frac{\frac{\alpha}{\alpha-1}}{\left(\frac{\alpha}{1-\alpha}+\frac{1}{1-\phi}\right)}\right) \frac{2-\alpha}{1-\alpha} \sum_{l=1}^{N}\left[-\left(\frac{1}{\left(1+\tau_{y_{j}}\right)}\right) \frac{q_{l s}}{\sum_{k=1}^{N} q_{k s}}\right]
$$

is the change in total revenue. The direct effect corresponding to $\beta$ is $\frac{2-\alpha}{1-\alpha}$, the indirect effect corresponding to $\theta$ is $\frac{\frac{\alpha}{\alpha-1}}{\left(\frac{\alpha}{1-\alpha}+\frac{1}{1-\phi}\right)}$, and knowing those parameters in addition to the share of output with access to the subsidies is sufficient for calculating the aggregate change in output due to a change in firm-specific subsidies, and similarly for calculating aggregate productivity growth. 


\section{B. CES utility over final goods}

In this section, I show that the direct and indirect effects derived in Section 3 have a similar functional form with CES utility. I only diverge from the baseline model by assuming that the representative consumer has CES utility over the final goods (and, as in the previous subsection, assuming labor as the only input to keep the intuition clear). In each sector, a single final good $Q_{s}$ is produced by a representative firm in a perfectly competitive market. The utility function of the representative consumer (who has exogenous income $I$ ) is therefore

$$
U=\left(\sum_{s=1}^{S} Q_{s}^{\frac{\phi-1}{\phi}}\right)^{\frac{\phi}{\phi-1}}
$$

where now $\phi$ is the same for each good, and represents the cross-sector elasticity of substitution. Given price $P_{s}$ in each sector, the aggregate price index is

$$
P=\left(\sum_{s=1}^{S}\left(P_{s}^{1-\phi}\right)\right)^{\frac{1}{1-\phi}}
$$

The revenue in sector $\mathrm{S}$ will therefore be

$$
Y_{s}=P_{s} Q_{s}=P_{s}^{1-\phi} P^{\phi-1} I
$$

Revenue for each intermediate good producer (who have constant-return to scale production functions in labor) will be

$$
\begin{aligned}
y_{j s} & =p_{j s} q_{j s} \\
& =\frac{P_{s}^{1-\phi} P^{\phi-1} I}{\left(P_{s}\right)^{1-\sigma}} p_{j s}^{1-\sigma} .
\end{aligned}
$$


VOL. NO.

Given (as in the main text) CES production from the representative final goods firms in each sector, Cobb-Douglas production from each intermediate goods producer, and firm-specific wedges of capital and labor, the growth rates of the final good producer's price, and the revenue and price of the intermediate good producer satisfy: ${ }^{1}$

$$
\begin{aligned}
\hat{y}_{j s} & =(1-\sigma) \hat{p}_{j s}+(\sigma-\phi) \hat{P}_{s}+(\phi-1) \hat{P} \\
\hat{P}_{s} & =\sum_{j=1}^{N_{s}}\left[\hat{p}_{s j} \frac{y_{j s}}{Y_{s}}\right] \\
\hat{p}_{j s} & =\left(\widehat{1+\tau_{L_{j}}}\right) .
\end{aligned}
$$

While $\hat{P}$ can be decomposed in a similar fashion to $\hat{P}_{s}$, it will affect each sector equally, and therefore will be absorbed by the time fixed effects in the regression. As a result, I omit its derivation. The change in each firm's revenue as a function of the changing wedges is therefore:

$$
\begin{aligned}
\hat{y}_{j s} & =(1-\sigma)\left(\left(\widehat{1+\tau_{L_{j}}}\right)\right) \\
& \left.+(\sigma-\phi) \sum_{j=1}^{N_{s}}\left[\left(\widehat{\left(1+\tau_{L_{j}}\right.}\right)\right) \frac{y_{j s}}{Y_{s}}\right] . \\
& +(\phi-1) \hat{P}
\end{aligned}
$$

The first line still reflects the direct effect of the program, which are unchanged relative to the main text. As inputs are relatively more subsidized (lowering the wedges), revenue will increase. The second and third lines reflect the indirect effect of the program, which captures how each firm's

\footnotetext{
${ }^{1}$ The notation is $\hat{x}=\frac{\dot{x}}{x}$ represents the growth of $\mathrm{x}$ over time.
} 
change in price changes the overall price index. As before, as $\sigma$ increases, the indirect effect will be relatively larger, and the derivations of $\beta$ and $\theta$ are simple.

\section{An Issue with Industry Codes}

In many settings researchers use industry codes instead of product codes, since product codes are unavailable. In other settings, Delgado, Porter and Stern (2015) and Hoberg and Phillips (2010) argue that industry codes are not the optimal way to group together product markets. In this section, I show that using industry codes as a proxy for competition may lead to biased estimates for the effects of competitive exposure, as firms will be assigned too much exposure to firms within their industry, and too little exposure to firms outside the industry. To see this, rewrite equation 14 (with an indicator $i_{k}=1$ for firm $k$ self-reporting as being in industry $i$ ) as

$$
\hat{y}_{j}=\beta e_{j}-\beta \theta \sum_{s=1}^{S} \omega_{j s}\left[\frac{\sum_{k=1}^{N_{s}} i_{k} \times e_{k} \times y_{k s}}{Y_{s}}+\frac{\sum_{k=1}^{N_{s}}\left(1-i_{k}\right) \times e_{k} \times y_{k s}}{Y_{s}}\right] .
$$

If instead I used the share of a firm's industry exposed to competition, I would generate

$$
\hat{y}_{j}^{\prime}=\beta e_{j}-\beta \theta \frac{\sum_{k=1}^{N} i_{k} \times e_{k} \times y_{k}}{Y_{i}} .
$$

The difference between the two measures is

$\hat{y}_{j}-\hat{y}_{j}^{\prime}=\beta \theta\left[\sum_{s=1}^{S} \frac{\omega_{j s}}{Y_{s}}\left(\left(\left(\sum_{k=1}^{N} i_{k} \times e_{k} \times y_{k}\right) \frac{Y_{s}}{Y_{i}}-\left(\sum_{k=1}^{N_{s}} i_{k} \times e_{k} \times y_{k s}\right)\right)-\left(\sum_{k=1}^{N_{s}}\left(1-i_{k}\right) \times e_{k} \times y_{k s}\right)\right)\right]$.

The first term $\left(\left(\sum_{k=1}^{N} i_{k} \times e_{k} \times y_{k}\right) \frac{Y_{s}}{Y_{i}}-\left(\sum_{k=1}^{N_{s}} i_{k} \times e_{k} \times y_{k s}\right)\right)$, can be 
decomposed further, to

$$
\left(\left(\sum_{s^{\prime} \neq s}^{S} \sum_{k=1}^{N} i_{k} \times e_{k} \times y_{k s^{\prime}}\right) \frac{Y_{s}}{Y_{i}}-\left(\left(\frac{Y_{s}}{Y_{i}}-1\right) \sum_{k=1}^{N_{s}}\left(i_{k} \times e_{k} \times y_{k s}\right)\right)\right) .
$$

$\left(\sum_{s^{\prime} \neq s}^{S} \sum_{k=1}^{N} i_{k} \times e_{k} \times y_{k s^{\prime}}\right) \frac{Y_{s}}{Y_{i}}$ captures the fact that each industry produces products which are produced in other industries. As a result, given the original model, there will be indirect effects which industries impose on outsiders. This will would lead one to overestimate the aggregate effects of firm specific programs if one estimated equation 9.

$\left(\left(\frac{Y_{s}}{Y_{i}}-1\right) \sum_{k=1}^{N_{s}}\left(i_{k} \times e_{k} \times y_{k s}\right)\right)$ captures the fact that each firm may not produce the same set of products as its own industry. This effect would lead one to underestimate the aggregate effects of firm specific programs if one estimated equation 9.

Finally, $\left(\sum_{k=1}^{N_{s}}\left(1-i_{k}\right) \times e_{k} \times y_{k s}\right)$ captures the fact that there may be firms in other industries who produce the same products as firm $j$. This effect will lead one to overestimate the aggregate effects if one estimated one estimated equation 9. In Appendix Table 3, I estimate the "effects" of the program change following equation 9. The estimated spillover effects are smaller in magnitude and less precise than those using product codes.

\section{Aggregate Effects of the Policy Change}

While it is not possible to separately identify the direct and the indirect effects of the eligibility expansion by looking at the aggregate effects, it is possible to examine their joint effect. I create an empirical analogue to 
Equation 13 by estimating equations of the form

$$
\ln \left(Y_{s t}\right)=\sum_{k} \beta_{\theta^{k}} \text { Post }_{t} \times \mu_{s}^{k}+\eta_{s}+\eta_{t}+\epsilon_{s t}
$$

in order to identify if sectors which are relatively more exposed to the policy change grow relatively quicker. ${ }^{2}$ The state/product regressions are also relatively sparse: almost all of the products do not appear in at least one year, and there is no way to know if that is because the product was not produced or if its producers just happened to not be sampled. An appealing features of the aggregate regressions is that they account for entry and exit dynamics, since I estimate the change on all activity, not just for firms whose eligibility status is known ex-ante.

Appendix Table 13 Column 1 tests the effects of exposure on the value of sectoral output, and finds effects consistent with the firm-level regressions presented earlier, although underpowered and insignificant. There are no predicted output gains for less-traded products (the point estimate is slightly negative), but increases in output for more-traded products. The next columns test the extent to which entry and exit mediate the effect of the subsidy program. For Column 2 the outcome is, for each state/product, the share of production made by firms who had previously never reported producing that product. This measure is clearly incorrect, as early on in the sample firms have more scope for producing products that appear new in the data (although there is no ex-ante reason to believe this would be dif-

2 In addition to being unable to separately identify the direct and indirect effects of the program, the aggregate effects are potentially less informative than the firm level regressions in the presence of product switching. If firms change their products in response to the policy change, then the effect on that firm's sales will potentially be very different than the estimated effect on that firm's old products. The regressions control for fourdigit product/state/year, year/product, and product/state fixed effects. 
ferentially true for more exposed products). Therefore, as a complimentary approach, in Column 4 I calculate for each product in its final post-program observation the share of output from firms who first started producing the product after 2005. Columns 3 and 5 report similar outcomes, but for new firms instead of new firm/products. There is no evidence that the subsidy program led to differential exit or entry, neither overall nor for more traded products. $^{3}$

\section{Omitted Variable Bias from the Indirect Effects}

Suppose Equation 11 is correct: firm growth as a function of the program is as in Equation 11, $\hat{y}_{j}=\beta e_{j}-\theta \beta \sum_{s}\left(\omega_{j s} \mu_{s}\right)+\left(\sum_{s}\left(\epsilon_{j s}+\epsilon_{s}\right)\right)$, but we naivly estimate

$$
\hat{y}_{j}=\tilde{\beta} e_{j}+\tilde{\epsilon}_{j}
$$

$\tilde{\beta}$ can be derived using the standard omitted-variable-bias formula:

$$
\tilde{\beta}=\beta-\theta \beta \frac{\operatorname{Cov}\left(e_{j}, \sum_{s}\left(\omega_{j s} \mu_{s}\right)\right)}{\operatorname{Var}\left(e_{j}\right)} .
$$

A firm being subsidized mechanically increases $\mu_{s}$ (since it is in its own sector), so we would expect $\tilde{\beta}$ to be biased downward relative to $\beta$.

\footnotetext{
${ }^{3}$ There is also no evidence that the extensive margin is important within firms: in a table available by request I recalculate firm's "exposure" each year, holding fixed $\mu_{s}$ but allowing for firms' product mix to evolve. There is no significant decrease in firm's exposure to the policy after 2005, suggesting that firms are unable to endogenously adjust their product mix to avoid directly competing with newly subsidized firms (or, alternatively, that both the newly subsidized firms and their competitors add similar products).
} 


\section{TFPQ for multi-product plants}

In the main text, I leverage the fact that, as pointed out by Hsieh and Klenow (2009), with CES demand firm-sector TFPQ can be backed out as

$$
\ln \left(A_{j s}\right)=\frac{\sigma}{\sigma-1} \ln \left(y_{j s}\right)-\sum_{\text {Input } \in L, K, M} \alpha_{\text {Input }_{j}} \ln \left(\text { Input }_{j s}\right) .
$$

With constant-returns to scale (which is mechanically imposed by costshares $)^{4}$ firm TFPQ is the weighted average of firm/sector TFPQ. A related object, the weighted average of $\ln \left(A_{j s}\right)$, is

$$
\sum \omega_{j s} \ln \left(A_{j s}\right)=\sum_{s}\left[\frac{\sigma}{\sigma-1} \omega_{j s} \ln \left(y_{j s}\right)-\omega_{j s} \sum_{\text {Input } \in L, K, M} \alpha_{\text {Input }_{j}} \ln \left(\text { Input }_{j s}\right)\right] .
$$

Plugging in that firm sector/input use is proportional to the revenue share;

$$
\sum \omega_{j s} \ln \left(A_{j s}\right)=\sum_{s}\left[\frac{\sigma}{\sigma-1} \omega_{j s} \ln \left(y_{j} \cdot \omega_{j s}\right)-\omega_{j s} \sum_{\text {Input } \in L, K, M} \alpha_{\text {Input }_{j}} \ln \left(\text { Input }_{j} \cdot \omega_{j s}\right)\right] .
$$

Pulling out the weights yields

$$
\sum \omega_{j s} \ln \left(A_{j s}\right)=\frac{\sigma}{\sigma-1} \ln \left(y_{j}\right)-\sum_{\text {Input } \in L, K, M} \alpha_{\text {Input }_{j}} \ln \left(\text { Input }_{j}\right) .
$$

As a result, the coefficients in Table 5 properly estimate the weighted average of $\ln \left(A_{j s}\right)$.

${ }^{4}$ Returns to scale are close to 1 in the estimates as well, for instance the De Loecker et al. (2016) method estimates returns to scale between .91 and 1.08 in Prowess and .97 and 1.07 in the ASI. 


\section{REFERENCES}

Delgado, Mercedes, Michael E Porter, and Scott Stern. 2015. "Defining clusters of related industries." Journal of Economic Geography, 16(1): 1-38.

De Loecker, Jan, Pinelopi K Goldberg, Amit K Khandelwal, and Nina Pavcnik. 2016. "Prices, markups, and trade reform." Econometrica, 84(2): 445-510.

Hoberg, G., and G. Phillips. 2010. "Product Market Synergies and Competition in Mergers and Acquisitions: A Text-Based Analysis." Review of Financial Studies, 23(10): 3773-3811.

Hsieh, Chang-Tai, and Peter Klenow. 2009. "Misallocation and manufacturing TFP in China and India." The Quarterly Journal of Economics, 124(4): 1403-1448.

Lucas, Robert E, Jr. 1978. "On the size distribution of business firms." The Bell Journal of Economics, 9(2): 508-523.

\section{Appendix Tables}




\section{Appendix Table 1: Tests for Firm-Size Manipulation}

Firms in year

Firms in final post-

categorized program observation

Firm Size Distribution around

0.011

$-0.006$

initial eligibility cutoff

$(0.008)$

(0.007)

Firm Size Distribution around

$-0.006$

$-0.003$

final eligibility cutoff

(0.006)

(0.007)

Notes: This table tests for evidence of manipulation around the eligibility cutoff by using deviations in the firm-size distribution, following Cattaneo et al (2017). 
Appendix Table 2. Other Effects of Priority Sector

\begin{tabular}{|c|c|c|c|}
\hline & $\begin{array}{c}\text { Firm Exists } \\
\text { (1) }\end{array}$ & $\begin{array}{l}\text { Sales Conditional on Survival } \\
\text { (2) }\end{array}$ & $\begin{array}{c}\text { Liabilities } \\
\text { (3) }\end{array}$ \\
\hline Post X "Small" & $\begin{array}{c}0.04 \\
(0.01)\end{array}$ & $\begin{array}{c}0.04 \\
(0.02)\end{array}$ & $\begin{array}{c}0.13 \\
(0.04)\end{array}$ \\
\hline Post X Within-State Exposure & $\begin{array}{l}-0.03 \\
(0.01)\end{array}$ & $\begin{array}{l}-0.01 \\
(0.03)\end{array}$ & $\begin{array}{l}-0.17 \\
(0.07)\end{array}$ \\
\hline $\begin{array}{l}\text { Post X Within-State } \\
\text { Traded Exposure }\end{array}$ & $\begin{array}{c}0.04 \\
(0.01)\end{array}$ & $\begin{array}{c}0.11 \\
(0.05)\end{array}$ & $\begin{array}{c}0.25 \\
(0.11)\end{array}$ \\
\hline Controls for: & & & \\
\hline $\begin{array}{l}\text { Share of firm's products that } \\
\text { are traded X Post } \\
\text { Firm FE } \\
\text { State/Year FE } \\
\text { Industry/Year FE }\end{array}$ & $\begin{array}{l}\text { Yes } \\
\text { Yes } \\
\text { Yes }\end{array}$ & $\begin{array}{l}\text { Yes } \\
\text { Yes } \\
\text { Yes }\end{array}$ & $\begin{array}{l}\text { Yes } \\
\text { Yes } \\
\text { Yes }\end{array}$ \\
\hline $\begin{array}{l}\text { Firms } \\
\text { Firm/Year Obs. }\end{array}$ & $\begin{array}{c}53,448 \\
229,556\end{array}$ & $\begin{array}{c}47,560 \\
206,001\end{array}$ & $\begin{array}{c}51,447 \\
219,135\end{array}$ \\
\hline
\end{tabular}

Notes: "Small" firms are those who gained eligibility in 2006. Each column represents a difference in differences specification, predicting the indicated outcome variable.

Observations are weighted by their (potentially time-varying) inverse sampling probability, and robust standard errors clustered by firm and industry/year are reported in parentheses.

Source: ASI 
Appendix Table 3. Direct + Indirect Effects of Priority Sector on Sales, using Industry Codes

\begin{tabular}{|c|c|c|c|c|c|c|}
\hline & $\begin{array}{l}\text { 3-digit } \\
\text { (1) }\end{array}$ & $\begin{array}{l}4 \text { digit } \\
(2) \\
\end{array}$ & $\begin{array}{l}5 \text { digit } \\
\text { (3) }\end{array}$ & $\begin{array}{l}\text { 3-digit (imputed) } \\
\text { (4) }\end{array}$ & $\begin{array}{l}4 \text { digit (imputed) } \\
\text { (5) }\end{array}$ & $\begin{array}{c}5 \text { digit (imputed) } \\
\text { (5) }\end{array}$ \\
\hline Post X "Small" & $\begin{array}{c}0.333 \\
(0.066)\end{array}$ & $\begin{array}{l}0.343 \\
(0.066)\end{array}$ & $\begin{array}{l}0.336 \\
(0.068)\end{array}$ & $\begin{array}{c}0.329 \\
(0.066)\end{array}$ & $\begin{array}{c}0.324 \\
(0.066)\end{array}$ & $\begin{array}{c}0.331 \\
(0.068)\end{array}$ \\
\hline Post X Within-State Exposure & $\begin{array}{l}-0.28 \\
(0.14)\end{array}$ & $\begin{array}{l}-0.42 \\
(0.13)\end{array}$ & $\begin{array}{l}-0.14 \\
(0.10)\end{array}$ & $\begin{array}{l}-0.23 \\
(0.14)\end{array}$ & $\begin{array}{l}-0.13 \\
(0.14)\end{array}$ & $\begin{array}{l}-0.11 \\
(0.11)\end{array}$ \\
\hline \multicolumn{7}{|l|}{ Controls for: } \\
\hline Firm FE & Yes & Yes & Yes & Yes & Yes & Yes \\
\hline State/Year FE & Yes & Yes & Yes & Yes & Yes & Yes \\
\hline Industry/Year FE & Yes & Yes & Yes & Yes & Yes & Yes \\
\hline Firms & 51,645 & 51,645 & 51,645 & 51,630 & 51,645 & 51,645 \\
\hline Firm/Year Obs. & 218,360 & 218,360 & 218,360 & 218,298 & 218,360 & 218,360 \\
\hline
\end{tabular}

Notes: "Small" firms are those who gained eligibility in 2006. Each column represents a difference in differences specification, predicting sales. Industry Codes are the firms self-reported 3,4, and 5 digit industries, as well as imputed industries based on the firm's major product. Observations are weighted by their (potentially time-varying) inverse sampling probability, and robust standard errors clustered by firm and industry/year are reported in parentheses. Source: ASI 
Appendix Table 4. Direct + Indirect (+ Trade) Effects of Priority Sector on Sales, using Industry Codes

\begin{tabular}{|c|c|c|c|c|c|c|}
\hline & $\begin{array}{l}\text { 3-digit } \\
\text { (1) }\end{array}$ & $\begin{array}{l}4 \text { digit } \\
(2)\end{array}$ & $\begin{array}{l}5 \text { digit } \\
\text { (3) }\end{array}$ & $\begin{array}{l}\text { 3-digit (imputed) } \\
\text { (4) }\end{array}$ & $\begin{array}{l}4 \text { digit (imputed) } \\
\text { (5) }\end{array}$ & $\begin{array}{c}5 \text { digit (imputed) } \\
\text { (5) }\end{array}$ \\
\hline Post X "Small" & $\begin{array}{c}0.318 \\
(0.067)\end{array}$ & $\begin{array}{c}0.329 \\
(0.067)\end{array}$ & $\begin{array}{c}0.321 \\
(0.069)\end{array}$ & $\begin{array}{c}0.317 \\
(0.067)\end{array}$ & $\begin{array}{c}0.310 \\
(0.067)\end{array}$ & $\begin{array}{c}0.320 \\
(0.069)\end{array}$ \\
\hline Post X Within-State Exposure & $\begin{array}{l}-0.45 \\
(0.19)\end{array}$ & $\begin{array}{l}-0.53 \\
(0.19)\end{array}$ & $\begin{array}{l}-0.30 \\
(0.14)\end{array}$ & $\begin{array}{l}-0.49 \\
(0.19)\end{array}$ & $\begin{array}{l}-0.16 \\
(0.19)\end{array}$ & $\begin{array}{l}-0.22 \\
(0.15)\end{array}$ \\
\hline $\begin{array}{l}\text { Post X Within-State } \\
\text { Traded Exposure }\end{array}$ & $\begin{array}{c}0.38 \\
(0.26)\end{array}$ & $\begin{array}{c}0.25 \\
(0.26)\end{array}$ & $\begin{array}{c}0.37 \\
(0.19)\end{array}$ & $\begin{array}{c}0.48 \\
(0.25)\end{array}$ & $\begin{array}{c}0.03 \\
(0.26)\end{array}$ & $\begin{array}{c}0.18 \\
(0.19)\end{array}$ \\
\hline \multicolumn{7}{|l|}{ Controls for: } \\
\hline Firm FE & Yes & Yes & Yes & Yes & Yes & Yes \\
\hline State/Year FE & Yes & Yes & Yes & Yes & Yes & Yes \\
\hline Industry/Year FE & Yes & Yes & Yes & Yes & Yes & Yes \\
\hline Firms & 50,587 & 50,587 & 50,587 & 50,572 & 50,587 & 50,587 \\
\hline Firm/Year Obs. & 214,064 & 214,064 & 214,064 & 214,002 & 214,064 & 214,064 \\
\hline
\end{tabular}

Notes: "Small" firms are those who gained eligibility in 2006. Each column represents a difference in differences specification, predicting sales. Industry Codes are the firms self-reported 3,4, and 5 digit industries, as well as imputed industries based on the firm's major product. Industries are classified as traded following Kothari (2014). Observations are weighted by their (potentially timevarying) inverse sampling probability, and robust standard errors clustered by firm and industry/year are reported in parentheses. Source: ASI 
Appendix Table 5. Direct + Indirect Effects of Priority Sector, Heterogeneous Effects on Sales by Product Characteristics

\begin{tabular}{|c|c|c|c|c|}
\hline & $\begin{array}{l}\text { High Capital Intensity } \\
\text { (1) }\end{array}$ & $\begin{array}{l}\text { High Borrowing Intensity } \\
\text { (2) }\end{array}$ & $\begin{array}{c}\text { Low Elasticity of Substitution } \\
\text { (4) }\end{array}$ & $\begin{array}{c}\text { Average Firm Size } \\
\text { (4) }\end{array}$ \\
\hline Post X "Small" & $\begin{array}{c}0.38 \\
(0.07)\end{array}$ & $\begin{array}{c}0.37 \\
(0.07)\end{array}$ & $\begin{array}{c}0.38 \\
(0.07)\end{array}$ & $\begin{array}{c}0.37 \\
(0.07)\end{array}$ \\
\hline Post X Within-State Exposure & $\begin{array}{l}-0.25 \\
(0.14)\end{array}$ & $\begin{array}{l}-0.32 \\
(0.15)\end{array}$ & $\begin{array}{l}-0.29 \\
(0.13)\end{array}$ & $\begin{array}{l}-0.23 \\
(0.16)\end{array}$ \\
\hline $\begin{array}{l}\text { Post X Within-State } \\
\text { Exposure by type }\end{array}$ & $\begin{array}{c}0.01 \\
(0.18)\end{array}$ & $\begin{array}{c}0.13 \\
(0.18)\end{array}$ & $\begin{array}{c}0.10 \\
(0.18)\end{array}$ & $\begin{array}{l}-0.04 \\
(0.19)\end{array}$ \\
\hline Controls for: & & & & \\
\hline $\begin{array}{l}\text { Share of firm's products that are } \\
\text { type X Post } \\
\text { Firm FE } \\
\text { State/Year FE } \\
\text { Industry/Year FE }\end{array}$ & $\begin{array}{c}\text { Yes } \\
\text { Yes } \\
\text { Yes } \\
\text { Yes }\end{array}$ & $\begin{array}{l}\text { Yes } \\
\text { Yes } \\
\text { Yes } \\
\text { Yes }\end{array}$ & $\begin{array}{c}\text { Yes } \\
\text { Yes } \\
\text { Yes } \\
\text { Yes }\end{array}$ & $\begin{array}{c}\text { Yes } \\
\text { Yes } \\
\text { Yes } \\
\text { Yes }\end{array}$ \\
\hline $\begin{array}{l}\text { Firms } \\
\text { Firm/Year Obs. }\end{array}$ & $\begin{array}{c}51,549 \\
218,086\end{array}$ & $\begin{array}{c}51,549 \\
218,086\end{array}$ & $\begin{array}{c}51,549 \\
218,086\end{array}$ & $\begin{array}{c}51,549 \\
218,086\end{array}$ \\
\hline
\end{tabular}




\section{Appendix Table 6. Robustness of Effects of Priority Sector to State by Industry by Year Controls}

\begin{tabular}{|c|c|c|c|c|c|}
\hline & $\begin{array}{l}\text { Sales } \\
(1)\end{array}$ & $\begin{array}{l}\text { Wages } \\
\text { (2) }\end{array}$ & $\begin{array}{l}\text { Capital } \\
\text { (3) }\end{array}$ & $\begin{array}{l}\text { Materials } \\
\text { (4) }\end{array}$ & $\begin{array}{c}\text { Total Flow Inputs } \\
\text { (5) }\end{array}$ \\
\hline Post X "Small" & $\begin{array}{c}0.38 \\
(0.07)\end{array}$ & $\begin{array}{c}0.12 \\
(0.03)\end{array}$ & $\begin{array}{c}0.19 \\
(0.06)\end{array}$ & $\begin{array}{c}0.36 \\
(0.07)\end{array}$ & $\begin{array}{c}0.35 \\
(0.07)\end{array}$ \\
\hline Post X Within-State Exposure & $\begin{array}{l}-0.39 \\
(0.12)\end{array}$ & $\begin{array}{l}-0.14 \\
(0.05)\end{array}$ & $\begin{array}{l}-0.30 \\
(0.10)\end{array}$ & $\begin{array}{l}-0.36 \\
(0.12)\end{array}$ & $\begin{array}{l}-0.35 \\
(0.12)\end{array}$ \\
\hline $\begin{array}{l}\text { Post X Within-State } \\
\text { Traded Exposure }\end{array}$ & $\begin{array}{c}0.55 \\
(0.20)\end{array}$ & $\begin{array}{c}0.20 \\
(0.09)\end{array}$ & $\begin{array}{c}0.47 \\
(0.17)\end{array}$ & $\begin{array}{c}0.42 \\
(0.19)\end{array}$ & $\begin{array}{c}0.47 \\
(0.19)\end{array}$ \\
\hline \multicolumn{6}{|l|}{ Controls for: } \\
\hline $\begin{array}{l}\text { Share of firm's products that } \\
\text { are traded X Post }\end{array}$ & Yes & Yes & Yes & Yes & Yes \\
\hline Firm FE & Yes & Yes & Yes & Yes & Yes \\
\hline State/IndustryYear FE & Yes & Yes & Yes & Yes & Yes \\
\hline Firms & 51,209 & 52,007 & 52,173 & 51,862 & 51,577 \\
\hline Firm/Year Obs. & 213,763 & 218,907 & 219,887 & 217,684 & 216,252 \\
\hline
\end{tabular}

Notes: "Small" firms are those who gained eligibility in 2006. Each column represents a difference in differences specification, predicting the indicated outcome variable. The predicted variable is how the (real) outcome affects aggregate productivity: $\ln$ (outcome) if positive, and 0 for closed establishments. Observations are weighted by their (potentially time-varying) inverse sampling probability, and robust standard errors clustered by firm and industry/year are reported in parentheses. Source: ASI 


\section{Appendix Table 7. Robustness of Effects of Priority Sector to Controlling for Assets}

\begin{tabular}{|c|c|c|c|c|c|}
\hline & $\begin{array}{c}\text { Sales } \\
(1)\end{array}$ & $\begin{array}{l}\text { Wages } \\
(2)\end{array}$ & $\begin{array}{c}\text { Capital } \\
\text { (3) }\end{array}$ & $\begin{array}{c}\text { Materials } \\
\quad(4)\end{array}$ & $\begin{array}{l}\text { Total Flow Inputs } \\
\text { (5) }\end{array}$ \\
\hline Post X "Small" & $\begin{array}{c}0.39 \\
(0.07)\end{array}$ & $\begin{array}{c}0.12 \\
(0.03)\end{array}$ & $\begin{array}{c}0.18 \\
(0.06)\end{array}$ & $\begin{array}{c}0.37 \\
(0.07)\end{array}$ & $\begin{array}{l}0.35 \\
(0.07)\end{array}$ \\
\hline Post X Within-State Exposure & $\begin{array}{l}-0.37 \\
(0.12)\end{array}$ & $\begin{array}{l}-0.12 \\
(0.05)\end{array}$ & $\begin{array}{l}-0.28 \\
(0.10)\end{array}$ & $\begin{array}{l}-0.33 \\
(0.11)\end{array}$ & $\begin{array}{l}-0.33 \\
(0.12)\end{array}$ \\
\hline $\begin{array}{l}\text { Post X Within-State } \\
\text { Traded Exposure }\end{array}$ & $\begin{array}{c}0.54 \\
(0.19)\end{array}$ & $\begin{array}{c}0.21 \\
(0.08)\end{array}$ & $\begin{array}{c}0.45 \\
(0.16)\end{array}$ & $\begin{array}{c}0.48 \\
(0.18)\end{array}$ & $\begin{array}{c}0.48 \\
(0.19)\end{array}$ \\
\hline $\begin{array}{l}\text { Controls for: } \\
\text { Cubic in Assets / Year }\end{array}$ & Yes & Yes & Yes & Yes & Yes \\
\hline $\begin{array}{l}\text { Share of firm's products that are } \\
\text { traded X Post }\end{array}$ & Yes & Yes & Yes & Yes & Yes \\
\hline Firm FE & Yes & Yes & Yes & Yes & Yes \\
\hline State/Year FE & Yes & Yes & Yes & Yes & Yes \\
\hline Industry/Year FE & Yes & Yes & Yes & Yes & Yes \\
\hline Firms & 51,549 & 51,549 & 51,549 & 51,549 & 0 \\
\hline Firm/Year Obs. & 218,086 & 218,086 & 218,086 & 218,086 & 0 \\
\hline
\end{tabular}

Notes: "Small" firms are those who gained eligibility in 2006. Each column represents a difference in differences specification, predicting the indicated outcome variable. The predicted variable is how the (real) outcome affects aggregate productivity: $\ln$ (outcome) if positive, and 0 for closed establishments. Observations are weighted by their (potentially time-varying) inverse sampling probability, and robust standard errors clustered by firm and industry/year are reported in parentheses. Source: ASI 
Appendix Table 8. Robustness of Effects of Priority Sector to Controlling for Other Product Characteristics

\begin{tabular}{|c|c|c|c|c|c|}
\hline & $\begin{array}{l}\text { High Capital Intensity } \\
\text { (1) }\end{array}$ & $\begin{array}{l}\text { High Borrowing Intensity } \\
\text { (2) }\end{array}$ & $\begin{array}{l}\text { Low Elasticity of Substitution } \\
\text { (3) }\end{array}$ & $\begin{array}{c}\text { Average Firm Size } \\
(4)\end{array}$ & $\begin{array}{l}\text { All } \\
(5)\end{array}$ \\
\hline \multirow[t]{2}{*}{ Post X "Small" } & 0.37 & 0.37 & 0.37 & 0.36 & 0.36 \\
\hline & $(0.07)$ & $(0.07)$ & $(0.07)$ & $(0.07)$ & $(0.07)$ \\
\hline \multirow[t]{2}{*}{ Post X Within-State Exposure } & -0.39 & -0.52 & -0.45 & -0.39 & -0.60 \\
\hline & $(0.15)$ & $(0.16)$ & $(0.15)$ & $(0.17)$ & $(0.29)$ \\
\hline Post X Within-State & 0.56 & 0.58 & 0.56 & 0.56 & 0.58 \\
\hline Traded Exposure & $(0.19)$ & $(0.20)$ & $(0.19)$ & $(0.19)$ & $(0.20)$ \\
\hline \multicolumn{6}{|l|}{ Controls for: } \\
\hline $\begin{array}{l}\text { Share of firm's products that } \\
\text { are traded X Post }\end{array}$ & Yes & Yes & Yes & Yes & Yes \\
\hline Firm FE & Yes & Yes & Yes & Yes & Yes \\
\hline State/IndustryYear FE & Yes & Yes & Yes & Yes & Yes \\
\hline Firms & 51,549 & 51,549 & 51,549 & 51,549 & 51,549 \\
\hline Firm/Year Obs. & 218,086 & 218,086 & 218,086 & 218,086 & 218,086 \\
\hline
\end{tabular}


Appendix Table 9. Robustness of Effects of Priority Sector to Alternative Exposure Calculations

\begin{tabular}{|c|c|c|c|c|c|}
\hline & $\begin{array}{c}\text { Sales } \\
(1)\end{array}$ & $\begin{array}{c}\text { Wages } \\
(2)\end{array}$ & $\begin{array}{l}\text { Capital } \\
\text { (3) }\end{array}$ & $\begin{array}{c}\text { Materials } \\
\text { (4) }\end{array}$ & $\begin{array}{c}\text { Total Flow Inputs } \\
\text { (5) }\end{array}$ \\
\hline Post X "Small" & $\begin{array}{c}0.37 \\
(0.07)\end{array}$ & $\begin{array}{c}0.11 \\
(0.03)\end{array}$ & $\begin{array}{c}0.17 \\
(0.06)\end{array}$ & $\begin{array}{c}0.35 \\
(0.07)\end{array}$ & $\begin{array}{c}0.33 \\
(0.07)\end{array}$ \\
\hline Post X Within-State Exposure & $\begin{array}{l}-0.42 \\
(0.12)\end{array}$ & $\begin{array}{l}-0.13 \\
(0.05)\end{array}$ & $\begin{array}{l}-0.31 \\
(0.10)\end{array}$ & $\begin{array}{l}-0.38 \\
(0.11)\end{array}$ & $\begin{array}{l}-0.36 \\
(0.12)\end{array}$ \\
\hline $\begin{array}{l}\text { Post X Within-State } \\
\text { Traded Exposure }\end{array}$ & $\begin{array}{c}0.56 \\
(0.19)\end{array}$ & $\begin{array}{c}0.19 \\
(0.08)\end{array}$ & $\begin{array}{c}0.44 \\
(0.16)\end{array}$ & $\begin{array}{c}0.51 \\
(0.18)\end{array}$ & $\begin{array}{c}0.48 \\
(0.19)\end{array}$ \\
\hline Controls for: & & & & & \\
\hline $\begin{array}{l}\text { Share of firm's products that } \\
\text { are traded X Post }\end{array}$ & Yes & Yes & Yes & Yes & Yes \\
\hline Firm FE & Yes & Yes & Yes & Yes & Yes \\
\hline State/IndustryYear FE & Yes & Yes & Yes & Yes & Yes \\
\hline Firms & 51,549 & 52,321 & 52,485 & 52,198 & 51,916 \\
\hline Firm/Year Obs. & 218,086 & 223,148 & 224,139 & 221,980 & 220,552 \\
\hline
\end{tabular}

Notes: "Small" firms are those who gained eligibility in 2006. Each column represents a difference in differences specification, predicting the indicated outcome variable. The predicted variable is how the (real) outcome affects aggregate productivity: $\ln$ (outcome) if positive, and 0 for closed establishments. Observations are weighted by their (potentially time-varying) inverse sampling probability, and robust standard errors clustered by firm and industry/year are reported in parentheses. Indirect exposure is defined as in the text, and products are considered traded if they are above median for (imports+exports)/ouput in the final pre-program year. Source: ASI 
Appendix Table 10. Robustness of Effects of Priority Sector to Alternative Exposure Calculations

\begin{tabular}{|c|c|c|c|c|c|}
\hline & $\begin{array}{c}\text { Sales } \\
(1)\end{array}$ & $\begin{array}{l}\text { Wages } \\
(2)\end{array}$ & $\begin{array}{c}\text { Capital } \\
\text { (3) }\end{array}$ & $\begin{array}{c}\text { Materials } \\
(4) \\
\end{array}$ & $\begin{array}{c}\text { Total Flow Inputs } \\
\text { (5) } \\
\end{array}$ \\
\hline Post X "Small" & $\begin{array}{c}0.44 \\
(0.07)\end{array}$ & $\begin{array}{c}0.13 \\
(0.03)\end{array}$ & $\begin{array}{c}0.23 \\
(0.06)\end{array}$ & $\begin{array}{c}0.42 \\
(0.07)\end{array}$ & $\begin{array}{c}0.40 \\
(0.07)\end{array}$ \\
\hline Post X Within-State Exposure & $\begin{array}{l}-0.56 \\
(0.13)\end{array}$ & $\begin{array}{l}-0.18 \\
(0.05)\end{array}$ & $\begin{array}{l}-0.45 \\
(0.11)\end{array}$ & $\begin{array}{l}-0.54 \\
(0.12)\end{array}$ & $\begin{array}{l}-0.52 \\
(0.13)\end{array}$ \\
\hline $\begin{array}{l}\text { Post X Within-State } \\
\text { Traded Exposure }\end{array}$ & $\begin{array}{c}0.41 \\
(0.19)\end{array}$ & $\begin{array}{c}0.16 \\
(0.08)\end{array}$ & $\begin{array}{c}0.31 \\
(0.16)\end{array}$ & $\begin{array}{c}0.40 \\
(0.18)\end{array}$ & $\begin{array}{c}0.36 \\
(0.19)\end{array}$ \\
\hline \multicolumn{6}{|l|}{ Controls for: } \\
\hline $\begin{array}{l}\text { Share of firm's products that } \\
\text { are traded X Post }\end{array}$ & Yes & Yes & Yes & Yes & Yes \\
\hline Firm FE & Yes & Yes & Yes & Yes & Yes \\
\hline State/IndustryYear FE & Yes & Yes & Yes & Yes & Yes \\
\hline Firms & 51,549 & 52,321 & 52,485 & 52,198 & 51,916 \\
\hline Firm/Year Obs. & 218,086 & 223,148 & 224,139 & 221,980 & 220,552 \\
\hline
\end{tabular}

Notes: "Small" firms are those who gained eligibility in 2006. Each column represents a difference in differences specification, predicting the indicated outcome variable. The predicted variable is how the (real) outcome affects aggregate productivity: $\ln$ (outcome) if positive, and 0 for closed establishments. Observations are weighted by their (potentially time-varying) inverse sampling probability, and robust standard errors clustered by firm and industry/year are reported in parentheses. Indirect exposure is defined as in the text, and products are considered traded if they are above median for (average exports)/(average ouput) over the five final pre-program years. Source: ASI 
Appendix Table 11. Robustness of Effects of Priority Sector to Alternative Exposure Calculations

\begin{tabular}{|c|c|c|c|c|c|}
\hline & $\begin{array}{c}\text { Sales } \\
(1)\end{array}$ & $\begin{array}{c}\text { Wages } \\
\text { (2) }\end{array}$ & $\begin{array}{c}\text { Capital } \\
\text { (3) }\end{array}$ & $\begin{array}{c}\text { Materials } \\
\text { (4) }\end{array}$ & $\begin{array}{c}\text { Total Flow Inputs } \\
\text { (5) }\end{array}$ \\
\hline \multirow[t]{2}{*}{ Post X "Small" } & 0.44 & 0.13 & 0.23 & 0.42 & 0.40 \\
\hline & $(0.07)$ & $(0.03)$ & $(0.06)$ & $(0.07)$ & $(0.07)$ \\
\hline \multirow[t]{2}{*}{ Post X Within-State Exposure } & -0.59 & -0.18 & -0.47 & -0.57 & -0.54 \\
\hline & $(0.13)$ & $(0.06)$ & $(0.11)$ & $(0.13)$ & $(0.13)$ \\
\hline Post X Within-State & 0.46 & 0.17 & 0.34 & 0.47 & 0.41 \\
\hline Traded Exposure & $(0.19)$ & $(0.08)$ & $(0.16)$ & $(0.17)$ & $(0.18)$ \\
\hline
\end{tabular}

Controls for:

Share of firm's products that are traded X Post

Firm FE

State/IndustryYear FE

$\begin{array}{lcccc}\text { Yes } & \text { Yes } & \text { Yes } & \text { Yes } & \text { Yes } \\ \text { Yes } & \text { Yes } & \text { Yes } & \text { Yes } & \text { Yes } \\ \text { Yes } & \text { Yes } & \text { Yes } & \text { Yes } & \text { Yes }\end{array}$

\begin{tabular}{lccccc} 
Firms & 51,549 & 52,321 & 52,485 & 52,198 & 51,916 \\
Firm/Year Obs. & 218,086 & 223,148 & 224,139 & 221,980 & 220,552 \\
\hline \hline
\end{tabular}

Notes: "Small" firms are those who gained eligibility in 2006. Each column represents a difference in differences specification, predicting the indicated outcome variable. The predicted variable is how the (real) outcome affects aggregate productivity: $\ln$ (outcome) if positive, and 0 for closed establishments. Observations are weighted by their (potentially time-varying) inverse sampling probability, and robust standard errors clustered by firm and industry/year are reported in parentheses. Indirect exposure is defined as in the text, and products are considered traded if they are above median for (average exports+imports)/(average ouput) over the five final pre-program years. Source: ASI 


\section{Appendix Table 12: Correlation of Tradability Measures}

Correlation with Main Measure

Main Measure

...exports + imports instead of exports

\#REF!

...average instead of final pre-program year

\#REF!

...both changes

\#REF!

Notes: This table tests for the reliability of the "tradability" measures, using the methods used in Table 5 and Appendix Tables 9, 10, and 11 
Appendix Table 13. Aggregate Effects of Priority Sector

\begin{tabular}{lccccc}
\hline \hline & $\begin{array}{c}\text { ln(Total Sales) } \\
(1)\end{array}$ & $\begin{array}{c}\text { Materials } \\
(2)\end{array}$ & $\begin{array}{c}\text { Wages } \\
(3)\end{array}$ & $\begin{array}{c}\text { Capital } \\
(4)\end{array}$ & $\begin{array}{c}\text { Total Flow Inputs } \\
(5)\end{array}$ \\
\hline Post X "Small" & -0.26 & 0.04 & 0.04 & 0.00 & -0.02 \\
& $(0.17)$ & $(0.03)$ & $(0.03)$ & $(0.02)$ & $(0.02)$ \\
& & & & & \\
Post X Traded Exposure & 0.41 & 0.01 & 0.01 & -0.02 & 0.03 \\
& $(0.43)$ & $(0.07)$ & $(0.07)$ & $(0.03)$ & $(0.03)$ \\
& & & & & \\
\hline Controls for: & & & & & Yes \\
State/Product FE & Yes & Yes & Yes & Yes & Yes \\
State/Year/Broad Sector FE & Yes & Yes & Yes & Yes & Yes \\
Product/Year FE & Yes & Yes & Yes & & 13,877 \\
Obs. & & & & 18,877 & \\
\hline \hline
\end{tabular}

Notes: Each observation represents a combination of state/product/year. Each column represents a difference in differences specification, predicting the indicated outcome variable. Only state/products in the data for at least $80 \%$ of the years are included. Source: ASI

Need to clarify some regressions are at the year level, others are state/year 
Appendix Table 14. Robustness of Effects to Dropping "Reserved" Products

\begin{tabular}{|c|c|c|c|c|}
\hline & $\begin{array}{c}\text { Strict } \\
\text { Produced Before } 2006\end{array}$ & $\begin{array}{c}\text { Strict } \\
\text { Ever Produced }\end{array}$ & $\begin{array}{c}\text { Fuzzy } \\
\text { Produced Before } 2006\end{array}$ & $\begin{array}{c}\text { Fuzzy } \\
\text { Ever Produced }\end{array}$ \\
\hline \multirow[t]{2}{*}{ Post X "Small" } & 0.38 & 0.38 & 0.37 & 0.37 \\
\hline & $(0.07)$ & $(0.07)$ & $(0.08)$ & $(0.08)$ \\
\hline \multirow[t]{2}{*}{ Post X Within-State Exposure } & -0.41 & -0.41 & -0.41 & -0.42 \\
\hline & $(0.12)$ & $(0.12)$ & $(0.13)$ & $(0.13)$ \\
\hline Post X Within-State & 0.59 & 0.60 & 0.69 & 0.72 \\
\hline Traded Exposure & $(0.20)$ & $(0.20)$ & $(0.21)$ & $(0.21)$ \\
\hline \multicolumn{5}{|l|}{ Controls for: } \\
\hline $\begin{array}{l}\text { Share of firm's products that } \\
\text { are traded X Post }\end{array}$ & Yes & Yes & Yes & Yes \\
\hline Firm FE & Yes & Yes & Yes & Yes \\
\hline State/IndustryYear FE & Yes & Yes & Yes & Yes \\
\hline Firms & 48,376 & 47,835 & 45,820 & 44,873 \\
\hline Firm/Year Obs. & 203,480 & 200,801 & 192,027 & 187,755 \\
\hline
\end{tabular}

Notes: "Small" firms are those who gained eligibility in 2006. Each column represents a difference in differences specification, predicting the indicated outcome variable. The predicted variable is how the (real) outcome affects aggregate productivity: $\ln$ (outcome) if positive, and 0 for closed establishments. Observations are weighted by their (potentially time-varying) inverse sampling probability, and robust standard errors clustered by firm and industry/year are reported in parentheses. Indirect exposure is defined as in the text. Firms are dropped if they produced products that were reserved for "small" firms, using the definitions in Martin et al. (2017). The coding for the reservations is different than that in the ASI, and they provide a conservative and fuzzy match. I drop firms from both lists who either produced the products before the policy change, or ever produced them. Source: ASI 
Appendix Table 15. Robustness of Effects of Priority Sector to Ignoring Informal Firms

\begin{tabular}{|c|c|c|c|c|c|}
\hline & $\begin{array}{c}\text { Sales } \\
(1)\end{array}$ & $\begin{array}{c}\text { Wages } \\
(2)\end{array}$ & $\begin{array}{l}\text { Capital } \\
\text { (3) }\end{array}$ & $\begin{array}{l}\text { Materials } \\
\text { (4) }\end{array}$ & $\begin{array}{l}\text { Total Flow Inputs } \\
\text { (5) }\end{array}$ \\
\hline \multirow[t]{2}{*}{ Post X "Small" } & 0.39 & 0.12 & 0.18 & 0.37 & 0.35 \\
\hline & $(0.07)$ & $(0.03)$ & $(0.06)$ & $(0.07)$ & $(0.07)$ \\
\hline \multirow[t]{2}{*}{ Post X Within-State Exposure } & -0.42 & -0.15 & -0.33 & -0.39 & -0.38 \\
\hline & $(0.12)$ & $(0.05)$ & $(0.10)$ & $(0.11)$ & $(0.11)$ \\
\hline Post X Within-State & 0.45 & 0.16 & 0.36 & 0.40 & 0.39 \\
\hline Traded Exposure & $(0.19)$ & $(0.08)$ & $(0.16)$ & $(0.18)$ & $(0.19)$ \\
\hline \multicolumn{6}{|l|}{ Controls for: } \\
\hline $\begin{array}{l}\text { Share of firm's products that } \\
\text { are traded X Post }\end{array}$ & Yes & Yes & Yes & Yes & Yes \\
\hline Firm FE & Yes & Yes & Yes & Yes & Yes \\
\hline State/IndustryYear FE & Yes & Yes & Yes & Yes & Yes \\
\hline Firms & 51,549 & 52,321 & 52,485 & 52,198 & 51,916 \\
\hline Firm/Year Obs. & 218,086 & 223,148 & 224,139 & 221,980 & 220,552 \\
\hline
\end{tabular}

Notes: "Small" firms are those who gained eligibility in 2006. Each column represents a difference in differences specification, predicting the indicated outcome variable. The predicted variable is how the (real) outcome affects aggregate productivity: $\ln$ (outcome) if positive, and 0 for closed establishments. Observations are weighted by their (potentially time-varying) inverse sampling probability, and robust standard errors clustered by firm and industry/year are reported in parentheses. Indirect exposure is defined as in the text, although I do not include informal firms (from the NSS) in the calcuations. Source: ASI 
Correlation with Main Measure

$\begin{array}{lc}\text { Main Measure } & - \\ \text { No NSS } & 0.97 \\ \text { Strict Drop SSI producers (From before Policy Change) } & 0.99 \\ \text { Strict Drop SSI producers (ever) } & 0.98 \\ \text { Fuzzy Drop SSI producers (From before Policy Change) } & 0.97 \\ \text { Fuzzy Drop SSI producers (ever) } & 0.96 \\ \text { 3 Digit Industry Codes } & 0.35 \\ 4 \text { Digit Industry Codes } & 0.35 \\ \text { 5 Digit Industry Codes } & 0.41 \\ \text { (Imputed) 3 Digit Industry Codes } & 0.41 \\ \text { (Imputed) 4 Digit Industry Codes } & 0.44 \\ \text { (Imputed) 5 Digit Industry Codes } & 0.58 \\ \text { All States } & 0.46 \\ \text { Not Own-State } & 0.19 \\ \text { Average pre-program } & 0.69\end{array}$

Notes: This table tests for the robustness of the exposure measures, for the robustness tables in the Appendix 
Appendix Table 17: Correlation of TFPQ Estimates

\begin{tabular}{lllll} 
Cost Shares (US) & Cost Shares (India) & W/LP & W/LP (Weighted) & DGKP (Prowess) \\
\hline
\end{tabular}

\author{
Cost Shares (US) \\ Cost Shares (India) \\ W/LP \\ W/LP (Weighted) \\ DGKP (Prowess) \\ DGKP (ASI)
}

0.74
0.72
0.74
0.93
0.76

0.74

0.72

0.93

0.76

-
0.93
0.96
0.62
0.98

0.96
0.59
0.92

0.62

0.95

0.65

Notes: This table tests the (unweighted) correlation of the (log \& industry demeaned) TFPQ measures. They are estimated using Cost Shares (in the NBER/CES data or and the ASI), Levinsohn and Petrin (2003) + Wooldridge (2009) in the ASI data, and De Loecker et al. (2016) (in the Prowess data or and the ASI). 


\section{Appendix Table 18: Sensitivity of Aggregate Productivity Estimates}

Observed Data

Adding Program Removing Program

Earlier

Afterwards

(2)

Main

$1.57 \%$

$-2.31 \%$

...exports + imports instead of exports

$1.50 \% \quad-2.30 \%$

....average instead of final pre-program year

$0.41 \%$

$-0.92 \%$

...both changes

$0.35 \%$

$-0.88 \%$

...earliest instead of most recent observations

$1.98 \%$

$-2.59 \%$

Notes: Each firm's contribution to aggregate productivity is affected by the Priority through three mechanisms in this table: direct size gains for the newly eligible, and indirect size losses for those who compete with the newly eligible, and effect which is mitigated by international trade. The table takes the coefficients in Table 5 and Appendix Tables 9, 10, and 11 Column (1) calculates the gains from introducing the program earlier (in each firms last pre-program observation), and column (2) calculates the gains from removing the program in each firms final observation. The last row uses the main estimates (from Table 5), but for firms in the first pre program (and first post-program) observations. 